\title{
Objectives, Function, and Teaching Material of Indonesian Literature in Curriculum KTSP and K13 at SMA Level
}

\author{
Eko Triono, Sarwiji Suwandi, \& Andayani \\ Sebelas Maret University \\ ekotriono_yes@yahoo.com; sarwijiswan@yahoo.com; bu_anda09@yahoo.co.id
}

\begin{abstract}
How to cite (in APA Style): Triono, E., Suwandi, S., \& Andayani (2019). Objectives, Function, and Teaching Material of Indonesian Literature in Curriculum KTSP and K13 at SMA Level. Jurnal Pendidikan Bahasa dan Sastra, 19(2), 186 - 197. DOI: https://doi.org/10.17509/bs_jpbsp.v19i2.24784
\end{abstract}

Article History: Received (24 October 2018); Revised (14 March 2019); Accepted (05 Mai 2019).

Journal homepage: http://ejournal.upi.edu./index.php/BS_JPBSP

\begin{abstract}
In its teaching, literature undergoes a change in approach along with curriculum changes. This study aims to 1) describe the purpose of teaching literature in curriculum KTSP and K13 at the level of high school; 2) to describe the function of literary teaching in the curriculum of KTSP and K13 in SMA; and 3) to describe the literary teaching materials in the curriculum of KTSP and K13 at SMA level. This research is qualitative descriptive type. The research data is obtained from document archive, informant, and textbook of Indonesian KTSP and K13. Data validity is done by triangulation method and data triangulation. Data collection techniques are content analysis and structured interviews. Data were analyzed interactively. The results of this research are the purpose of teaching literature in KTSP and K13 at SMA level is that students are able to analyze and create literary works, as well as develop individual and social character through literary works. The function of literary teaching in KTSP and K13 is to make literary works as a means of achieving language skills. Third, the literary teaching materials in KTSP and K13 are short stories, poems, plays, novels, reviews.
\end{abstract}

Keywords: curriculum; teaching literature; KTSP; K13

\section{Tujuan, Fungsi, dan Bahan Ajar Sastra Indonesia dalam Kurikulum KTSP dan K13 di Tingkat SMA}

\begin{abstract}
Abstrak: Dalam pengajarannya, sastra mengalami perubahan dalam pendekatan bersama dengan perubahan kurikulum. Penelitian ini bertujuan untuk 1) mendeskripsikan tujuan pengajaran sastra dalam kurikulum KTSP dan K13 di tingkat sekolah menengah; 2) untuk menjelaskan fungsi pengajaran sastra dalam kurikulum KTSP dan K13 di SMA; dan 3) mendeskripsikan bahan ajar sastra dalam kurikulum KTSP dan K13 di tingkat SMA. Penelitian ini merupakan penelitian deskriptif kualitatif. Data penelitian diperoleh dari arsip dokumen, informan, dan buku teks KTSP dan K13 Indonesia. Validitas data dilakukan dengan metode triangulasi dan triangulasi data. Teknik pengumpulan data berupa analisis isi dan wawancara terstruktur. Data dianalisis secara interaktif. Hasil dari penelitian ini yaitu tujuan pengajaran sastra di KTSP dan K13 di tingkat SMA adalah agar siswa dapat menganalisis dan membuat karya sastra, serta mengembangkan karakter individu dan sosial melalui karya sastra. Fungsi pengajaran sastra di KTSP dan K13 adalah menjadikan karya sastra sebagai sarana untuk mencapai keterampilan berbahasa. Ketiga, bahan ajar sastra di KTSP dan K13 merupakan cerita pendek, puisi, drama, novel, ulasan.
\end{abstract}

Kata kunci: kurikulum; pengajaran kesusastraan; KTSP; K13 


\section{INTRODUCTION}

In the history of the concept, the curriculum is taken from a term that refers to the path that must be taken by a runner (Oliva, 1982, p. 4). This trajectory is adopted in the context of teaching as a learning trajectory, so Taba (in Kurniasih \& Sani, 2013, p.5) calls the curriculum a teaching plan. Beauchamp (in Hamdani, 2013, p.15-17) also agreed that the curriculum is a teaching plan and as a system that is part of the schooling system. Literary teaching is related to the curriculum, both curriculum as actualization and as planning (curriculum as a plan for experiences) (Oliva, 1982, p.10). In the curriculum, as a set of plans and arrangements regarding the purpose, content, and learning materials as well as ways used as guidelines for the implementation of learning activities to achieve certain educational goals (Law Number 20 of 2003, Article 1 point 19), there is literature teaching material as a line great to be taught by the teacher in the classroom. Therefore, it is necessary to research the purpose, function and material of teaching Indonesian literature in terms of its curriculum (a plan for experiences) in the KTSP and 2013 curriculum, especially at the high school level. The selection of the levels was carried out because of the characteristics of the complexity of literary teaching in high schools that were more than the previous level and so that the study was more focused.

Literary teaching is important in its position, not only in relation to language and literary skills, but in a broader scope related to character and interdisciplinary education. The relationship between teaching literature and character education cannot be separated. Landt (2011, p.1) suggests that through literary work students can use various perspectives in seeing things, including using other people's perspectives, so that their character will be honed.

Literature is still taught at high schools in Indonesia. In its teaching, literature undergoes a change in approach along with curriculum changes. This change is a necessity. In his research, Varbelow (2012, p. 87 ) uses the postmodern curriculum theory of William Doll to know the shift from premodern to posmodern and its implications for education. Varbelow (2012, p.87) gives an idea that the curriculum is a product of time (product of time) (Oliva, 1982, p.30). Therefore, the curriculum continues to change (continuous proces) (Oliva, 1982, p.40). The change from Education Unit Level Curriculum (KTSP) to Curriculum K13 (K13) also marks some changes in teaching approaches in it, including Indonesian language teaching where literature is integrated. This change takes place with regard to the purpose, function, and literary teaching materials in it.

This study aims to 1) describe and explain the purpose, function and material of teaching Indonesian literature in the KTSP and 2013 curriculum at the high school level; 2) describe and explain the similarities and differences between the objectives, functions and materials of teaching Indonesian literature in the KTSP and 2013 curriculum at the high school level; 3) describe and explain the development of the objectives, functions and materials of literary teaching in Indonesia in the KTSP and 2013 curriculum at the high school level.

The purpose of this literary teaching has a problem gap. In Basir's study (2017), entitled Aspects of "Literature" in the Indonesian Curriculum: A Number of Structured Problems, suggests too much the purpose of teaching literature in K13 compared with KTSP. In fact, according to Oemarjati (1992), the purpose of literary teaching is important, namely an effective mission to enrich the student experience and make it more responsive to events around him. Meanwhile, Dharma (2017) said that the ideal goal of literary learning in schools is a literary appreciation. With different views on the teaching of literature in schools, it is necessary to do research related to the purpose of teaching this literature, especially in KTSP and K13.

Literary teaching places literature in a series of functions to achieve the purpose of teaching itself. Atmazaki (2013), in his study states that Indonesian language in K13 is 
based on text so that it can be called Textbased Curriculum) so that its implementation is called text-based teaching and learning, also called genre-based teaching and learning. Suherli, et al. (2017, p.5) this textual approach by involving elements contained in the Content Language Integrated Learning (CLIL) that highlighted 4 important elements as sharpening the definition of language competence, namely content, language / communication (communication), cognition cognition), and culture (culture). The focus on this text raises a problem, because in one of his theories, Tanaka divides the literary system into two parts, the micro-literary system and the macro-literary system (Mahayana, 2011, p.2). In the macro system, literature is overwhelmed by cultural circles, publishers and mass media, literary teaching as a spearhead, and literary criticism. So, literature is not just the literary text itself. Thus, in its function it must be re-examined the literary position in its teaching, especially in the KTSP and K13 related to the positioning of the position on the position should be. The function of literary teaching can run only if there is literary material taught.

About the material problem in K13, Rohmah (2017) in his research entitled Geliat Literature Industry in Schools: Creative Industry-Based Literature Learning reveals that in the K13 curriculum, for one year in Class X learners will study 4 types of texts; text of observation reports, exposition texts, complex procedural texts, anecdotal texts, negotiated texts, it means that literary learning is given only once a year to learners, ie only anecdotal text, no specific study of literature and the products produced in the literature. This condition should be compared with similar portions in the KTSP to see how far the gap changes in literary teaching materials. This is because the ideal conditions in the teaching of literature that is with the distribution of a number of literary competencies in one level of education.

Based on the ideal condition scales and the reality in the application of KTSP and K13 in learning Indonesian language, especially Indonesian literature, this research needs to be done to describe and explain the main things related to Indonesian language learning, namely function, purpose, and material. The importance of this research is done so that understanding of changes in literary learning in KTSP and K13 can be placed more comprehensively by looking at more complex data through documents, archives and textbooks, as well as interviews with teachers. Thus, there is no partial understanding of literary learning in KTSP and $\mathrm{K} 13$ as in previous similar studies. A comprehensive and in-depth presentation is useful for fundamental understanding related to the position of literary learning in Indonesian language learning in KTSP and K13 as well as in other curricula in the future.

\section{METHOD}

The study period starts from May to October 2017. This research has been conducted at the Center of Curriculum and Bookkeeping, Yogyakarta, and Surakarta. The type of approach and strategy of this research is descriptive qualitative. This study utilizes written data from curriculum archives and documents containing literary teaching materials, as well as information from informants. This approach and strategy is used to describe and explain various information about the objectives, functions, and literary teaching materials in Indonesia in the curriculum KTSP and K13 at the senior high school level.

The source of this research data comes from archives, documents, and informants. Archives are generally formal records (Sutopo, 2006,p.41). The archive to be used is a copy of the curriculum decision of KTSP and K13 at SMA level. The data of this research use document in the form of notes, reviews, or comments on curriculum policy of KTSP and K13 on SMA level especially related to objectives, functions, and literary teaching materials, derived from news, essays in mass media, papers, books, or results research. In addition, the data comes from informants. Informants who used as the source of this research data is the teacher of language and literature Indonesia level SMA. 
Data collection techniques applied in the research are content analysis and structured interviews. Validity of data used in this research is triangulation data and triangulation method. The data analysis technique used in this research is using interactive model of analysis proposed by Miles \& Huberman (in Sutopo, 2006: 113121).

\section{RESULTS AND DISCUSSION}

KTSP is seen as having a number of weaknesses. In Indonesian language learning, KTSP has not placed social functions in the text and is still centered on mastering the text itself. In 2013, 2013 Curriculum (K13) was developed with a language learning approach using the latest theories. The approach taken is genrebased, pedagogy genre, and CLIL (integrated learning content language). In this approach, the text is functioned socially. The social purpose text that is intended is namely report (report), recount, explanation, exposition (discussion, response review), description (description), procedure (procedure), and narrative. Text is defined as a way to communicate. Communication can be written, oral, or multimodal.

The CLIL approach combines content and language. The thematic-integrative term in the 2013 curriculum is the realization of the application of CLIL. 4C as the application of CLIL, namely content, communication, cognition, culture (community / citizenship). Content is related to what topic (in this case is the topic of science such as ecosystems). Communication is related to what type of language is used (for example comparing, reporting). In this section the concept of genre is applied, how a type of text is structured (text structure) and what form of language is often used in that type of text. Cognition is related to what thinking skills are required regarding topics (eg identifying, classifying). Culture is related to the local content of the surrounding environment that is related to the topic, for example the specificity of plants in the area where students learn, including the problems of character and language attitude. Scientific Approach and Genre Pedagogy are used in the learning process. The scientific approach is used to develop independent learning and critical attitudes towards facts and phenomena.

The Indonesian language learning approach with KTSP and K13 also influences the learning of Indonesian literature. The influence of this development should have a positive impact that makes literary literacy of Indonesian students and society in general, experiencing significant development. In fact, Basir (2017) research results entitled "Literature Aspects" in the Indonesian Language Curriculum: A number of Structured Problems, suggest that the aim of teaching literature in the K13 is too broad compared to KTSP. In fact, according to Oemarjati (1992), the purpose of teaching literature is important, namely an effective mission to enrich student experience and make it more responsive to events around him. Meanwhile, Dharma (2017) said that the ideal goal of literary learning in schools is literary appreciation. Given the different views on literary teaching in schools, it is necessary to conduct research related to the purpose of teaching this literature, especially in KTSP and K13.

This research produced some of the findings related to the objectives, fungtion, and literary teaching materials in KTSP and K13. The findings of this study is a summary of research results obtained from interviews, curriculum document analysis, and literary teaching material analysis in Indonesian language textbooks based on KTSP and K13. 


\section{Teaching Objectives in KTSP and K13}

Table 1 Equation of Literary Teaching Objectives in KTSP and K13 at SMA Level

\begin{tabular}{|c|c|c|}
\hline No. & Curriculum & Finding \\
\hline 1. & $\begin{array}{l}\text { KTSP and } \\
\text { K13 }\end{array}$ & $\begin{array}{l}\text { Students are able to analyze and create literary works, as well as develop } \\
\text { individual and social character through literary works. Analyze is preceded } \\
\text { by the ability to understand, appreciate, and respond. Creating literary works } \\
\text { is built with the ability to construct. Individual characters include refining } \\
\text { the character, broadening insight, and increasing knowledge about the } \\
\text { values of life. Social characters include appreciating and praising the literary } \\
\text { and intellectual treasures of Indonesia, and taking social attitudes associated } \\
\text { with literature in community life. }\end{array}$ \\
\hline
\end{tabular}

In a study conducted by Basir (2017) entitled Aspects of "Literature" in the Indonesian Curriculum: A Number of Structured Problems resulted in the findings that in Curriculum KTSP, Indonesian subjects put more emphasis on language skills (and literature), whereas in K13, Language Learning Indonesia is used as a means to develop the skills and skills of reasoning. The problematic teaching of curriculum literature $\mathrm{K} 13$ is related to the goal of too broad the purpose of teaching literature. This goal, according to the research of Rohmah (2017), namely Literary Industry Geliat in School: Literary Learning Based on Creative Industry, should emphasize appreciative activities, because literature is an art that can be produced and appreciated so that learning should be productiveappreciative.

Text-based literary teaching in K13 in Kusumaningsih's (K13) research in Indonesian Text Role as Draft Science in Curriculum K13: Assessment Introduction Text Structure Strategies in the Indonesian Book, using some basic principles of expectation:

1) the language should be used as a text, not merely a collection of words or linguistic rules, 2) the use of language is a process of selecting the forms of language to express meaning, 3) functional language is the use of language that is never out of context because it is the kind of language used reflects the ideas, attitudes, and its ideology, and 4) language is a means of forming the ability of human thinking.
Thus, as expressed by Muti'ah (2015) in his research, that learning Indonesian based on KTSP and K 13 leads to the development of literacy skills (reading and writing).

The objective presented by Basir (2017) namely in the KTSP put forward the skills of language and literature, while in K13 develop the skills and skills of reasoning, not entirely true. This is because, both in KTSP and K13, both emphasize the ability to analyze. Ability analysis cannot happen without the reasoning skills. Likewise, the skills of language and literature must be based on the skills of reasoning, because the literature has the structure and characteristics that require analytical skills. Basir (2017) also reveals too broad the purpose of literary teaching in K13. Based on the research findings, this is true with the scope of competence outside the literature itself as depicted in Core Competence (KI).

Based on these conditions, the result of Rohmah (2017) research which emphasizes the objective of productive-apreciative literary teaching has actually existed, both in KTSP and K13. Not only is it appreciativeproductive, but also as what Kusumaningsih (K13) reveals contains attitude and character functions. These characters include individual characters and social characters. Individual characters in the form of refining the character, broaden the horizons, and increase knowledge about the values of life. Social characters include appreciating and praising the literary and intellectual treasures of Indonesia, and taking social attitudes associated with literature in community life. 
Muti'ah (2015) suggests the goal or estuary of literary teaching that is literacy (reading and writing). In K13, the position of literacy itself becomes even a triad in Indonesian language learning, namely Indonesian, literature, and literacy. Not just literacy in literacy, but also other types of literacy. In $\mathrm{K} 13$ also, as stated by Judge (2017), the purpose of this literary teaching is that students are able to communicate ideas and express themselves. This is in line with the National Education System Act No. 20 of 2003 which states that the purpose of literary learning is to realize the atmosphere and the learning process so that learners are actively developing their potential to have spiritual spiritual strength, self-control, personality, intelligence, noble character, and skills needed himself, society, nation and state.

Table 2 The Differences of KTSP and K13 Literary Teaching Objectives

\begin{tabular}{lll}
\hline No. & Curriculum & \multicolumn{1}{c}{ Finding } \\
\hline 1. & KTSP & $\begin{array}{l}\text { It aims to have students master the variety of literary works and things } \\
\text { around the literary works itself, as well as the literary theory. There are } \\
\text { writers, literary history, and literary criticism }\end{array}$ \\
2 & K13 & $\begin{array}{l}\text { Focusing on literary texts. Have not put explicitly about the author, literary } \\
\text { history, and literary criticism. }\end{array}$ \\
\hline
\end{tabular}

The function of literary teaching at K13 as a means of analyzing text as revealed by Atmazaki (K13) in the implementation of Curriculum K13 Indonesian Subject: Mindset, Scientific Approach, Text (Genre), and Authentic Assessment that Indonesian in K13 rests on text so that it can be called textbased curriculum so that the implementation is called text-based teaching and learning, also called genre-based teaching and learning. Based on the research findings, the position of literary texts in the KTSP also serves as a pedestal. The pedestal is approached by a communicative method, so that the work of literature serves as a means to achieve language skills with listening approach, speaking, reading, and writing. The aim of teaching literature is to make students able to master aspects of literary work both intrinsically and extrinsically. The intended intiksik is the whole component in the type of literary work. The component is bound in linguistic rules, because literature is written using language. Each literary work has a different character and element. Poetry has characteristics that distinguish it from prose fiction and drama. Mastery of these characteristics begins with reading the existing examples and ends with the ability to analyze the elements.
In the extrinsic aspect, it not only finds the values contained in the literary work and its relationship with society, but also positions and communicates literary works within the community itself as part of reflexions of the situation or in K13 which leads to social functions. Mastery of extrinsic aspects is an added value of literary material. Learning material must not be uprooted from real life. Literary work presents reflection on reality in society with their respective methods, both poetry, fiction prose, and drama.

In the next stage after mastering the material, students are asked to be able to use literary methods in expressing their thoughts and feelings. The purpose of literary teaching does not end in a cognitive test of the material, but on the ability to apply literary text methods on various occasions. Conditions that are expressed are not just individual conditions, but conditions of the community in which students are located. In this way, there is an applied reflection of science on literary texts and dialectics of individual and social life. The purpose of complex literary teaching is to create a climate of literacy. Reading literacy is not only an index of reading and writing skills, but also the ability to dialectic and discuss in work, including literary works. 
A thriving community is a society that constantly discusses its existence and finds things that need to be improved. The low level of literacy in Indonesia is due to the purpose of literary learning which ends only with knowledge without the application of that knowledge. The result is the lack of production of Indonesian literary books compared to developed countries.

\section{Literary Teaching Function of KTSP and K13}

Table 3. Equation of KTSP Literary Teaching Function and K13

\begin{tabular}{|c|c|c|}
\hline No. & Curriculum & Finding \\
\hline 1. & $\begin{array}{l}\text { KTSP and } \\
\text { K13 }\end{array}$ & $\begin{array}{l}\text { KTSP and K13 Making literary works as a means to achieve language } \\
\text { skills.Namely by using a variety of literary works such as poetry, fiction } \\
\text { prose, and drama. }\end{array}$ \\
\hline
\end{tabular}

With the same textual characteristics, K13 approaches it with different methods, so that the function of literary teaching in some cases shifts or understands, especially with viewing. The approach taken is by genrebased, pedagogy genre, and CLIL by making literary texts function as a means of understanding, appreciating, responding, analyzing, and creating. Competence is listening, reading, viewing, speaking, and writing. The basic function is to make literary works as a means of achieving language skills.

Table 4. Differences in KTSP and K13 Literary Teaching Functions

\begin{tabular}{lll}
\hline No. & Curriculum & \multicolumn{1}{c}{ Finding } \\
\hline 1. & KTSP & $\begin{array}{l}\text { With a communicative approach to make literary work serves as a means to } \\
\text { achieve language skills with listening approach, speaking, reading, and } \\
\text { writing. Without viewing }\end{array}$ \\
& $\begin{array}{l}\text { With genre-based, pedagogy genres, and CLIL by making literary texts } \\
\text { function as a means of understanding, appreciating, responding, analyzing, } \\
\text { and creating. Competence is listening, reading, viewing, speaking, and } \\
\text { writing. }\end{array}$
\end{tabular}

Haris (2017) in his research entitled Differences Analysis between Curriculum KTSP and Curriculum K13 found a number of characteristics of material differences in Indonesia discuss junior high, high school, and vocational school at KTSP and K13. Indonesian language on KTSP (1) taught material is emphasized on grammar and language structure, (2) students are not accustomed to read and understand the text presented, (3) students are not accustomed to compose text, systematic, logical and effective, (4) ) students are not introduced about text rules that suit their needs, (5) less emphasis on the importance of expression and spontaneity in the language. (2) students are accustomed to read and understand the meaning of texts and to summarize and reprint with their own language, (3) the content of the language of $\mathrm{K} 13$ is characterized by (1) the taught material is emphasized on language competence as a communication tool to convey ideas and knowledge; students are familiarized with constructing appropriate texts so that they are systematic, logical and effective through text-composing exercises, (4) students are introduced with appropriate textual rules so as not to be confused in the process of composing text (according to the circumstances: what, who, where), and (5) students are accustomed to be able to express themselves and their knowledge in spontaneously persuasive language. Literary teaching is present in schools because literature is seen as having a number of benefits so that it can function. Sayuti (2002: 35) mentions that the benefits of literary 
works are very possible to be achieved, because literature provides an unlimited opportunity (meaning) to the audience. The delivery of literary benefits to the audience according to Lukens (in Nurgiyantoro, 2004: 206) because literature offers two main things, namely pleasure and understanding. Literature is present to the reader first of all is to provide entertainment, fun entertainment. After providing entertainment, literature provides benefits related to the values of life. This is because literary works are essentially elevated from life and talk about life itself.

In the K13 literary learning function develops by making it a means to analyze the text as expressed by Atmazaki (2013) in his writing entitled Implementation of the 2013 Indonesian Language Curriculum: Mindset, Scientific Approach, Text (Genre), and Authentic Assessment that Indonesian language in $\mathrm{K} 13$ relies on text so that it can be called a Text-Based Curriculum so that in its implementation it is called text-based teaching and learning, usually called genrebased teaching and learning. Based on the research findings, the position of literary text in KTSP also functions as a support. The approach is approached with a communicative method, so that the literary work serves as a means of achieving language skills with the approach of listening, speaking, reading, and writing.

With the characteristics of the same text, K13 approaches it with different methods, so the function of literary learning in some ways shifts or persists, especially with the presence of viewing. The approach taken is by genrebased, pedagogy genre, and CLIL by making literary text function as a means of understanding, appreciating, responding, analyzing, and creating. The competence is listening (listening), reading (reading), viewing (viewing), speaking (speaking), and writing (writing). Its basic function is the same as making literature as a means to achieve language skills.

\section{Literature Teaching Material}

Table 5. Equation of KTSP and K13 Literature Teaching Material

\begin{tabular}{lll}
\hline No. & Curriculum & \multicolumn{1}{c}{ Finding } \\
\hline 1. & KTSP and & $\begin{array}{l}\text { Short stories, poems, plays, novels, reviewsWith more concise, poetry, } \\
\text { fiction prose, drama, and reviews. The material is related to the knowledge } \\
\text { of the genre and the skill of creating the genre. }\end{array}$ \\
\hline
\end{tabular}

Literary learning has different characteristics from other learning materials. Oemarjati (1992,p.2) suggests that literary learning generally becomes more interesting if the material can provoke experience and bring students' creativity. Suryaman (2010) explained that in a competency-based curriculum, literary appreciation learning has a target of mastering three competencies, namely: (1) appreciation or appreciation competence; (2) expression competency; and (3) creative competence (productive).

The research titled Aspects of "Literature" in Indonesian Curriculum: A Number of Structured Problematics by Basir (2017) suggests that In the 2006 Curriculum, Indonesian subjects put more emphasis on language skills (and literature), while in
Curriculum K13, Indonesian Learning is used as a means to develop the skills and skills of reasoning. in the K13 curriculum, in the learning of Indonesian in class X SMA there are five materials taught in the form of text. The text is the text of the observed report, the exposition text, the text of the complex procedure, the anecdotal text, and the negotiating text. For one year, students only study one literary text, an anecdotal text. When compared with language material, then 1: 4 literature with language. It is beyond reasonable considering the learning of literature helps students develop reason. The problems of teaching curriculum literature $\mathrm{K} 13$ at least there are 4 problems that until now have not received serious handling. (2) inadequate supporting facilities, (3) lack of 
professional literary teachers, and unbalanced time allocation allocations.

Table 6. Differences in KTSP and K13 Literary Teaching Material

\begin{tabular}{lll}
\hline No. & Curriculum & \multicolumn{1}{c}{ Finding } \\
\hline 1. & KTSP & $\begin{array}{l}\text { There is material (1) folklore, (2) old poetry, literary history; (3) classical } \\
\text { Malay literature and (4) saga, (5) popular novels, (6) translation novels, (7) } \\
\text { literary criticism, (8) literary essays, and authors; (9) biography of literary } \\
\end{array}$ \\
& $\begin{array}{l}\text { figures } \\
\text { There are materials (a) anecdotes, (b) re-stories, (c) monologues, and (d) film } \\
\text { texts. }\end{array}$
\end{tabular}

About the material in KTSP and K13 Rohmah (2017) in his research revealed that in the K13 curriculum, for one year learners will study 4 types of texts; text of observation reports, exposition texts, complex procedural texts, anecdotal texts, negotiated texts, it means that literary learning is given only once a year to learners, ie only anecdotal text, no specific study of literature and the products produced in the literature. Literature is the creative process that produces the product; if it returns to KTSP, the learning of class X literature will result.

The material does not always work according to expectations. Haris (2017) in his research found a number of characteristics of differences in material in Indonesian at junior high, high school and vocational level in KTSP and K13. Indonesian language material on KTSP (1) the material taught is emphasized on grammar and language structure, (2) students are not accustomed to reading and understanding the text presented, (3) students are not accustomed to composing text, which is systematic, logical and effective, (4) students are not introduced to the rules of the text according to their needs, (5) less emphasis on the importance of expression and spontaneity in language. Indonesian language material in K13 has characteristics, namely (1) The material taught is emphasized on language competence as a communication tool to convey ideas and knowledge, (2) students are accustomed to reading and understanding the meaning of the text and summarizing and restating it in their own language, (3) students are accustomed to composing appropriate texts so that they are systematic, logical, and effective through text compilation exercises, (4) students are introduced to appropriate text rules, so that they are not ambiguous in the process of textual compilation (according to situations and conditions: what, who , where), and (5) students are accustomed to being able to express themselves and their knowledge with a convincing language spontaneously.

Literary learning is based on literature, namely what and how the literature is taught. Literature has a main component consisting of a variety of literary works, authorship and society where literature is located, reading or criticizing it, and utilizing works for certain interests, both theoretical and practical. These interests are at the level of ideology, politics, and established in education.

Literary material content in terms of its variety consists of poetry, fiction prose, and drama. The film text that appears in K13 can be correlated with the latest drama development that underlies sintematography and requires a film script to make it happen. Understanding of each variety that needs to be deepened by literary teachers to facilitate the learning process. This is because the change in KTSP and K13 is the learning approach, while the material taught does not experience significant changes. Thus, literary instructors should understand poetry and be able to write poetry, understand fiction prose and be able to write fiction prose, understand drama and be able to write drama scripts and perform dramas, and also at the level of expression in other forms. Mastery of this variety, makes literary teachers master the 
material and is not easily confused when there is a change or the development of literary learning approaches through improvements or curriculum development in the future.

The next component is the authorship that accompanies the presence of literary works. Without the author of a literary work will not be born. Mastery of authorship as teaching material can include historicallychronological authors of each era, author psychology, as well as author sociology as a socio-cultural representation of the place where the author lives. Mastery of the historical-chronological aspect by literary teaching and its placement by literary learning policy makers, makes literary learning has historical content that involves the development of literary history, as well as the history of a nation's own civilization. By developing this component, it means intentionally that an educational model deprives itself of the roots of the nation that built it through the dialectics of previous generations, including the dialectics summarized in various literary works in various eras, both pre-colonial, colonial, and postcolonialism in Indonesia. In the psycholgical aspects of learning about the author concerning the attitude of life of the author who represents the various attitudes of life of Indonesian people with various tribes and nations. In this way, students have a tolerance attitude in the context of diversity in a single life of nation and state. In the sociological aspect, the social picture of each literary work is able to provide a responsive value to the social variety of life around students. Literature makes students have the best attitudes towards existing social differences.

In the aspect of reading or criticism, placing literary work as an active object that must be responded with critical reasoning and then used to criticize other social conditions. With critical power, students will develop into individuals who are aware of their role. This can be done through learning literary works, especially learning literary criticism. Active readers are readers who are needed in the millennial generation today.
False information can spread, because of the decline in critical power to constantly correct information that is present in the community. Literary criticism can be a means so that students are accustomed to attitudes that do not receive information in various forms immediately without filtration.

In the aspect of the use of literary works for learning other material outside of literary works, literary instructors can consciously know the content of literary works that collects complex things in society. Society as a literary body and the direction of literary purposes has all aspects of life, ranging from economics, politics, social, law, culture, defense, security, science, and other things. With such awareness, especially in integrated CLIL, literary or non-literary teachers can use literary works as a means of teaching character, history, economics, ecology, law, psychology, geography, botany, chemistry, anthropology and so on.

Understanding the basic aspects of literary learning material makes the teacher not lose the teaching orientation and also lack the material to teach literature. Understanding of this aspect is only possible if early literary learning masters the components in literary work in depth, not only on the surface.

\section{CONCLUSION}

First, the purpose of teaching literature in KTSP and K13 at SMA Level is that students are able to analyze and create literary works, as well as develop individual and social character through literary works. Analyze is preceded by the ability to understand, appreciate, and respond. Creating literary works is built with the ability to construct. Individual characters include refining the character, broadening insight, and increasing knowledge about the values of life. Social characters include appreciating and praising the literary and intellectual treasures of Indonesia, and taking social attitudes associated with literature in community life. The difference in the purpose of literary teaching lies in the coverage of achievements obtained by students in the teaching of 
literature. In the KTSP, the scope is so that students master the variety of literary works and things around the literary works itself, as well as literary theory. There are writers, literary history, and literary criticism. At K13, it focuses on literary texts. Have not made explicit the author, literary history, and literary criticism as part of the literature itself.

Secondly, the function of literary teaching in KTSP and K13 is to make literary works as a means to achieve language skills. The function is done by using a variety of literary works such as poetry, fiction prose, and drama. Literature, arranged in language, serves as a medium for students to practice how to express their thoughts and feelings through a variety of literary works. Each variety has a different structure that can be enabled by students for their language communication needs. The distinction of this function lies in the way to place literary work in teaching. In the KTSP, literary works are taught with a communicative approach, which makes literary works serve as a means of achieving language skills with listening, speaking, reading, and writing approaches. Without viewing. In K13, literary works are seated with genres-based, pedagogy genres, and CLIL by making literary texts function as a means of understanding, appreciating, responding, analyzing, and creating. Competence is listening, reading, viewing, speaking, and writing.

Third, the literary teaching materials in KTSP and K13 are short stories, poems, plays, novels, reviews. With more concise, poetry, fiction prose, drama, and reviews. The material is related to the knowledge of the genre and the skill of creating the genre. Short stories are taught with the archetypes of students looking at short story examples, then understanding the structure and its elements. In the next stage students are asked to write short stories and read them. In the poetry, novels, and stage reviews are also not much different. In the drama material, the student's final stage of writing the drama script and staging the drama. The difference lies in the variety of material in which KTSP uses literary concepts that include literary works themselves, literary authors, and literary criticism. In KTSP there is material that is not in K13 (1) folklore, (2) old poetry, literary history; (3) classical Malay literature and (4) saga, (5) popular novels, (6) translation novels, (7) literary criticism, (8) literary essays, and authors; (9) biography of literary figures. Also in K13 there are materials that have not yet appeared in the KTSP: (a) anecdotes, (b) stories, (c) monologues, and (d) film texts. The literary material in $\mathrm{K} 13$ in textbooks in several meetings was raised not as literary texts, but in other texts. For example the emergence of poetry material on the text of procedures in the form of poetry reading procedures. Likewise, the poetry text is used as the basis for building the text of opinion.

\section{REFERENCES}

Atmazaki. (2013). Implementasi Kurikulum K13 Mata Pelajaran Bahasa Indonesia: Pola Pikir, Pendekatan Ilmiah, Teks (Genre), dan Penilaian Otentik. Prosiding The International Seminar on Language and Arts. FBS Universitas Negeri Padang.

Basir, U. Pr. M. (2017). Aspek "Kesastraan" dalam Kurikulum Bahasa Indonesia: Sejumlah Problematika Terstruktur. Prosiding Seminar Nasional Bahasa dan Sastra Indonesia dalam Konteks Global, PS PBSI FKIP Jember University.

Dharma, Y. W. E. (2017). Teori Sastra dalam Pembelajaran Sastra Kurikulum 2013 Tingkat SMA dan Implementasinya di SMA Negeri 2 Yogyakarta. Pend. Bahasa dan Sastra Indonesia-S1, 6(4), 531-545.

Hamdani, H. (2013). Pengembangan Kurikulum Pendidikan. Bandung: CV.Pustaka Setia.

Kurniasih, I. \& Sani, B. (2014). Implementasi Kurikulum 2013: Konsep \& Penerapan. Surabaya: Kata Pena.

Landt, S. M. (2011). Integration of Multicultural Literature in Primary Grade Language Arts Curriculum. The Journal of Multiculturalism in Education, 7, pp. 1-27. St. Norbert College

Mahayana, M.S. (2011). 'Visi dan Misi Kesusastraan Indonesia Abad XXI', dalam Bahasa, Sastra, dan Budaya 
Indonesia dalam Jebakan Kapitalisme: Persembahan Purna Karya Drs. B. Rabmanto, M. Hum (editor Yosep Adi Taum, I. Praptomo Baryadi, dan S.E. Peni Adji). Yogyakarta: Sanata Darma University.

Muti'ah, A. (2015). Pembelajaran Bahasa Indonesia di antara Dua Kurikulum dan Peranannya dalam Pengembangan Literasi. Prosiding Seminar Konferensi Bahasa dan Sastra III. Universitas Sebelas Maret, Surakarta (pp. 386-392).

Nurgiyantoro, B. (2004). Kontribusi Sastra Anak dalam Pembentukan Kepribadian Anak. Jurnal Cakrawala Pendidikan, 2(2).

Rohmah, M. (2017). Geliat Industri Sastra di Sekolah: Pembelajaran Sastra Berbasis Industri Kreatif. Journal of PENA Indonesia, Jurnal Babasa dan Sastra Indonesia serta Pengajarannya, 3(1).

Varbelow, S. (2012). Instruction, Curriculum and Society: Iterations Based on The Ideas of William Doll. International Journal of Instruction, 5 (1), 86-98.
Oemarjati, B.S. (1992). Pengajaran Sastra pada Pendidikan Menengah di Indonesia: Quo Vadis?. Paper in Konferensi Internasional Himpunan Sarjana-Kesusastraan Indonesia (HISKI), 18-21 August 2005.

Oliva, P.F. (1982). Developing the Curriculum. Boston: Little, Brown and Company.

Sayuti, S. A. (2002). Sastra dalam Perspektif Pembelajaran dalam Sarumpaet, RKT, Sastra masuk sekolah. Jakarta: Indonesiatera.

Suherli, Suryaman, M., Istiqomah, \& Septiaji, A. (2017). Bahasa Indonesia; Buku Bahasa Indonesia untuk SMA/SMK Kelas XI. Jakarta: Pusat Kurikulum dan Perbukuan, Balitbang, Kemendikbud.

Suryaman, M. (2010). Pendidikan karakter melalui pembelajaran sastra. Jurnal Cakrawala Pendidikan, 1(3).

Sutopo, H. B. (2006). Penelitian kualitatif: Dasar teori dan terapannya dalam penelitian. Surakarta: Universitas Sebelas Maret. 